\title{
The influence of product attribute, promotion mix, distribution channel, and price toward repurchase intention on iPhone
}

\author{
Antonius Satria Hadi \\ Entrepreneurship Study Program, Faculty of Economics, Widya Mataram University, \\ Yogyakarta, Indonesia
}

\begin{abstract}
Article History
Received : 27 June 2021

Revised : 22 August 2021

Accepted : 26 August 2021

Published : 27 August 2021
\end{abstract}

\section{Keywords:}

product attribute; promotion mix; distribution channel; price; repurchase intention

\section{Corresponding author:}

antonius_satria@widyamataram.ac.id

DOI:

10.20885/AMBR.vol1.iss2.art2

\begin{abstract}
The purpose of this research is to examine the effect of product attribute on repurchase intention, the effect of promotion mix on repurchase intention, the influence of distribution channel on repurchase intention, and the effect of price on repurchase intention, both partially and simultaneously. Respondents in this study were 99 students from several universities in Yogyakarta. The analytical technique used in this research is multiple linear regression analysis, $\mathrm{F}$ test and $t$ test. All tests using IBM SPSS software version 23. The results of this study prove that product attribute has a positive effect on repurchase intention, price has a positive effect on repurchase intention, and promotion mix has a positive effect on repurchase intention. Each of hypotheses discussed in detail into this article.
\end{abstract}

\section{Introduction}

In the era of globalization of trade as it is today, the business world faces very tight competition. Marketing activities are one of the important factors and must be carried out by every company in order to face the competition and to maintain its survival and for the development of its business. Intense competition in the business world demands the attitude of every company to always be able to anticipate every change and all possibilities that occur in the business environment. In order to compete in the global market, companies must be able to market the products they produce and this is one of the important factors in achieving the company's success which will later be marked by the intention to repurchase the company's products ( $\mathrm{Li}$ et al., 2020; Ji \& Ha, 2021).

The increasingly advanced era of globalization also has an impact on the progress of the business world where the market is becoming wider and opportunities are more spread out, as well as competition in the business world is getting tougher. With the emergence of new companies entering the market and trying to shift existing companies to gain market share, the competition between companies is becoming increasingly competitive. In order for the company to continue to exist and develop in this era, the company must have a competitive advantage. To be able to have a competitive advantage, one way is that the company must be able to give satisfaction to consumers by meeting consumer demands and needs so that consumers are willing to buy the company's products/services repeatedly for the survival of the company (Jeon et al., 2021; Rasmikayati et al., 2021). Besides that, in order for companies to overcome this competition, a marketing strategy is needed. Marketing activities are not only the company's ability to deliver goods from producers to consumers, but also find ways to make consumers feel satisfied (Urdea et al., 2021).

There are several variables in the marketing strategy, including products, prices, distribution channels, and promotions commonly known as the marketing mix (Kotler \& Keller, 2016). Every company should implement the appropriate marketing mix so that it can compete with other companies and the goal of maintaining the company's survival will be achieved. The elements in the marketing mix variables are closely related to each other. Therefore the company must be able to combine it appropriately in its implementation. In other words, the role of the marketing mix 
cannot be separated from a business that occurs in the company. Every company wants consumers to always repurchase the products it produces (Mendoza, 2021).

The role of technology in the current era of globalization is very important, because humans are required to think ahead and move faster. The technology that is currently growing is information and communication technology. The integration between technological developments and informatics has resulted in the evolution of mobile phones into smartphones. Smart because this phone has a high ability in its operation and can combine several functions of computer devices (PCs), mobile phones and supported with certain operating systems (Backer, 2010; Hadi, 2018).

Previous researchers (Williams \& Sawyer, 2011) stated that a smartphone is a cellular phone with a built-in microprocessor, memory, display and modem. So it can be concluded that smartphone is a multimedia phone that combines the functionality of a computer or PC and a handset to produce a luxurious gadget, that has cameras, music players, video player, games, email access, digital television, search engines, personal information managers, GPS features, internet telephone services and can even function as a credit card. The presence of smartphones has actually been around since 1994 and is marketed on a limited basis. The first smartphone was produced by IBM and was called the Simon Personal Communicator (SPC). SPC at that time already had an LCD touch screen, $16 \mathrm{MHz}$ NEC V30HL CPU, 1MB RAM, 1MB internal memory, and a 7.5V battery capacity. Therefore SPC is able to operate a number of smart jobs, such as sending and receiving faxes, pages, and emails. SPC can even store notes, calendars, and arrange meeting schedules. But at that time, SPC was still intended for enterprises and the price was very expensive (Tocci, 2020).

iPhone is one of the smartphone brands that compete in global competition. iPhone is a smartphone produced by a technology company from the United States and is the flagship product of Apple.Inc. Began to be developed and marketed to all global markets in 2007 and there were not many mobile phone products that developed in the global market. When it was first launched in 2007, iPhone was immediately considered one of the greatest mobile phone innovations ever. Since then until now, the development and change of high-end smartphones continues to be a conversation every year (Lo et al., 2018; Yun et al., 2019). In its development, since making the $2 \mathrm{G}$ model in 2007, Apple has continued to develop its products to keep it updated according to the times. When compared, all of these devices from the very first to the newest, namely iPhone 12 Pro Max, all have experienced an increase in specifications which will certainly make the activities of their users easier. In Figure 1 it can be seen that the number of iPhone users from year to year is increasing and even reaches 1 billion in 2020 .

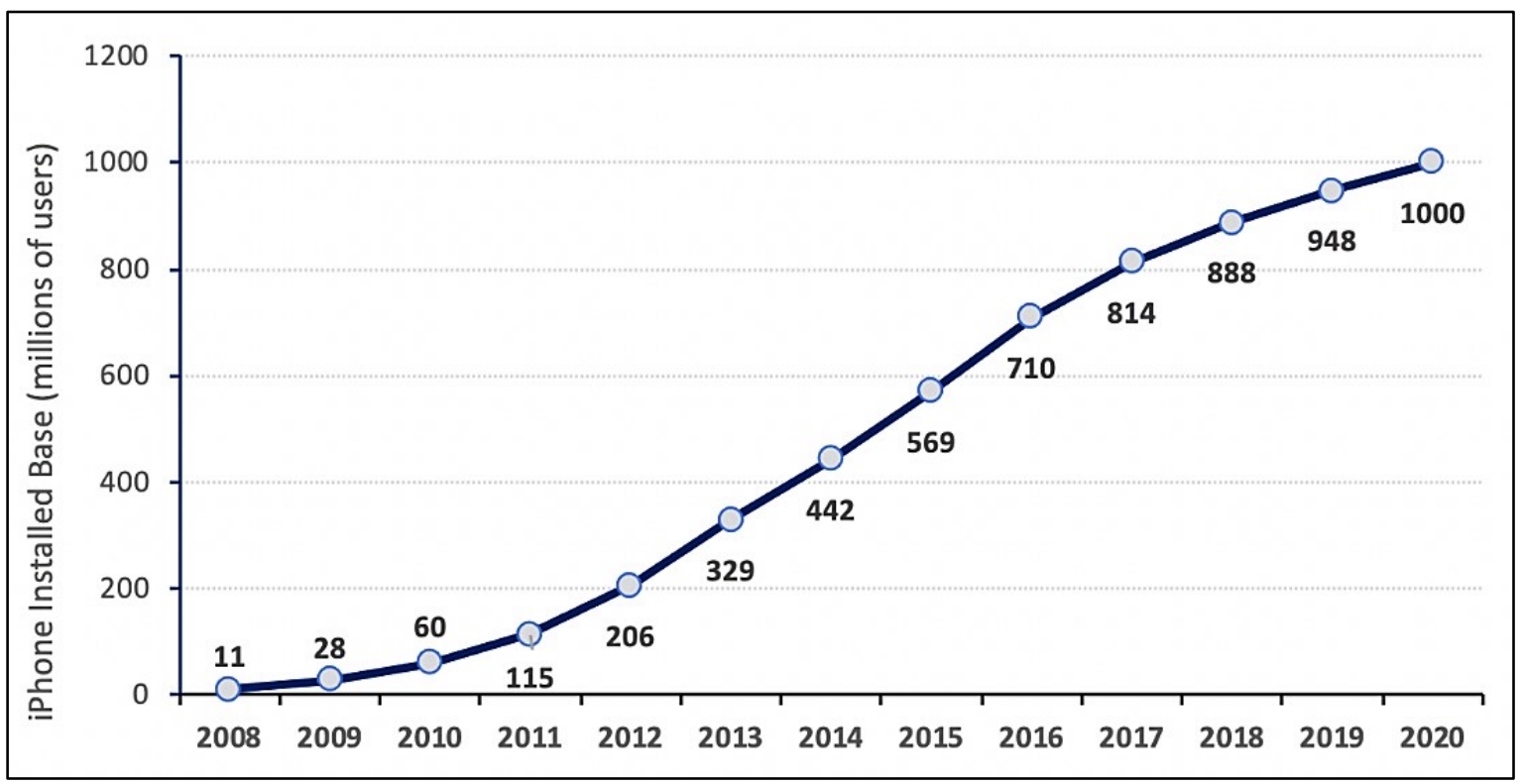

Figure 1. Number of iPhone users in the world (source: https://www.aboveavalon.com/notes/2020/10/26/a-billion-iphone-users) 


\section{Literature Review and Hypotheses Development}

\section{Product Attribute}

In an effort to develop a product or service, it is necessary to pay attention to the benefits that will be offered. These benefits can be communicated and given to consumers through product attributes, such as quality, features, as well as style and design (Kotler \& Keller, 2016; Kotler \& Armstrong, 2017). Product attributes are elements that are considered important by consumers and are used as the basis for making repurchase decisions. Attributes that can be added to a product include brand, packaging, and labels. According to Solomon (2018), the product attribute variables are brand, packaging, label, product design, colour, product quality, product warranty \& product liability and product servicing. Brand is also an attribute that provides non-material benefits, namely emotional satisfaction. Product attributes are product elements that are considered important by consumers and are used as the basis for making purchasing decisions. The product elements include: brand, packaging, guarantee, service, and others (Puspaningrum, 2018).

Meanwhile, previous researchers (Lovelock \& Wright, 2011) define product attributes as all features (both tangible and intangible) of an item or service that can be assessed by customers. This product attribute will distinguish between the products offered by a company with similar products offered by other companies. These attribute differences can then lead to differences in consumer perceptions of the products offered by various companies so that they can ultimately influence consumers in purchasing decisions or repurchase intentions. In addition, product quality is also considered as an element attached to a product and is considered important by consumers. Consumers buy products after seeing the features and designs contained in the product. Products that have attractive product attributes will certainly generate consumer interest in making repeat purchases. Product attributes will ultimately provide positive results in the form of benefits to consumers. That's why product attributes are a consideration for consumers who are interested in a product and decide to buy the product (Lee et al., 2012; Butcher et al., 2019). From some of these definitions it can be concluded that product attributes are the elements that make up a product, where each attribute has a different capacity in making decisions for consumers and product attributes are very important things to be considered by consumers to be taken into consideration in making decisions for purchase or repurchase of a product. Product attributes have an important role in influencing consumers to make repurchase decisions. This is because product attribute variables such as product quality, brand, design \& style are the main factors in influencing repurchase intention of the product (Song et al., 2020). Therefore, the more attractive the product attributes in iPhone, the higher consumer's repurchase intention towards iPhone.

\section{Promotion Mix}

Companies need to develop a strategy to communicate the products they offer to consumers by using various promotional tools to attract visitors and create purchases. Promotion is one of the variables in the marketing mix that needs to be implemented by companies in marketing products and services. The willingness of consumers to buy products or services on the basis of satisfaction which is the result of feedback from the company's promotional activities, so that companies know that their information is received by consumers positively. According to Kadar (2018), promotion is a process to communicate products in the form of goods and services in an effort to persuade consumers to be willing to accept, give members or even provide good recommendations for the company's products they receive. Promotion is faced with various kinds of activities that companies can do to communicate the advantages of their products in order to persuade potential buyers. Therefore, marketing managers must choose the right and integrated form of promotion in order to produce a domino effect so as to increase sales volume (Gherasim et al., 2012; Ji \& Ha, 2021).

Meanwhile, the promotion mix can be used as one of the most important things to increase sales of a company. Promotion mix is a communication tool consisting of a combination of promotional tools used by the company. In general, these promotional tools have a close relationship, so that they cannot be separated, because they are mutually supportive and complementary. In line with this, efforts that can be made in marketing a product are by carrying 
out promotional activities which include, advertising, sales promotion, personal selling, public relations, direct marketing so that prospective consumers are more familiar with, understand, and understand the products offered (Hersh \& Aladwan, 2015; Kotler \& Armstrong, 2017; Attia et al., 2018; Fikri \& Lisdayanti, 2020). Etzel et al. (2017) stated that the promotional mix is the best combination of strategies from the variables of advertising, personal selling and other promotional tools that are all planned to achieve the objectives of the sales program. Hence, the more attractive the promotion mix, the higher consumer's repurchase intention toward iPhone.

\section{Distribution Channel}

In its sales, the company in addition to conducting sales activities also establishes several agents in its distribution in the hope that the product will be more easily accessible to consumers. Distribution is a marketing activity that aims to facilitate the delivery of products (goods and services) from producers to consumers (Armstrong \& Kotler, 2015; Gazdecki, 2018). Meanwhile, distribution channel is a marketing intermediary channel for both transportation and storage of a product (goods and services) from the hands of producers to consumers. Distribution channels include the problem of choosing which products to use to distribute, as well as developing a distribution system that physically handles and involves products through these channels. This is intended so that the product can reach the target market more effectively and efficiently (Vlad \& Pavel, 2017; Tošović et al., 2020).

A company must be good at distributing its products. The company must be able to see market opportunities to distribute its products, not only in local or national markets but also international. Besides that, the company must be good at determining the selling price, especially in the international market, because the company must cooperate with cargo and use distribution costs that are quite expensive which have an impact on the selling price of the product. All of this is done so that the company's products can be reached by all consumers (Yarosh \& Mitina, 2020; Chang et al., 2021). Assuming that the easier it is for consumers to get the product, the higher the intention to repurchase. This is what the iPhone does in satisfying consumer needs (products are easy to get). So, the easier it is for consumers to get products, the more they will increase their repurchase intentions.

\section{Price}

According to Gherasim \& Gherasim (2019), price is one of the factors that have a significant influence on consumer purchase intentions. If the selling price of a product is too high, there is a possibility that consumers will switch to competing products or substitute products. When consumers compare prices and product features, consumers tend to be rational. Consumers compare the benefits of money obtained with the price to be paid. Several other studies have also stated that price is an important consideration and has an influence positive on purchase intention. When consumers are in the decision-making process, price is the product attribute that is most often considered when evaluating products. (Thabit \& Raewf, 2018; Simanjuntak et al., 2020; Pham \& Huynh, 2020).

Price is an attribute of a product that is most often used by some consumers to evaluate a product. Price is the main factor that is always considered in a decision to select and purchase a product. High prices can be viewed favorably and positively by certain market segments (Kim et al., 2020). It is due to the result of the balance or equilibrium. Equilibrium according to Mankiw (2012) is a situation where the market price has reached a level where the quantity of products offered by producers is equal to the quantity of products demanded by consumers. In the equilibrium price curve there is a meeting point between the demand curve and the supply curve, which is called the equilibrium price. The equilibrium price according to Pindyck \& Daniel (2018) is the price that balances the quantity supplied from producers and the quantity demanded from consumers. At the equilibrium price, the supply by producers who are willing to release the product, while the demand by consumers who are willing to pay the price. According to Kotler \& Armstrong (2017) to measure price variables, the indicators are price affordability, price conformity with product quality, price competitiveness, price suitability with production benefits. Price perception 
greatly influences consumer decisions to buy a product. Price perception relates to how price information is fully understood by consumers and gives deep meaning to them. One approach to understanding price perception is information processing (Peter \& Olson, 2010). Consequently, the more competitive the price will increase the consumer's repurchase intention of the iPhone.

\section{Repurchase Intention}

Satisfied customers will buy again, and they will tell others about their experience using the product. Smart companies are not just looking for profit, but intend to deliver more than what they promise. Consumers buy a product not because of the physical form alone but rather the benefits they will get after using the product. Repurchase according to Handoko (2017) is a purchase that has been made by a buyer for the same product, and will buy again for the second or third time. Muhammad et al. (2019) and Ji \& Ha states that the response caused by past positive experiences received to make repeated purchases is called repurchase intention. From the explanation above, the hypotheses proposed in this study are:

$\mathrm{H}_{1}$ : Product attributes, promotion mix, distribution channel and price simultaneously has a positive effect on consumer's repurchase intention toward iPhone

$\mathrm{H}_{2}$ : Product attributes has a positive effect on consumers' repurchase intentions toward iPhone

$\mathrm{H}_{3}$ : Promotion mix has a positive effect on consumers' repurchase intentions toward iPhone

$\mathrm{H}_{4}$ : Distribution channels has a positive effect on consumers' repurchase intentions toward iPhone $\mathrm{H}_{5}$ : Price has a positive effect on consumers' repurchase intentions toward iPhone

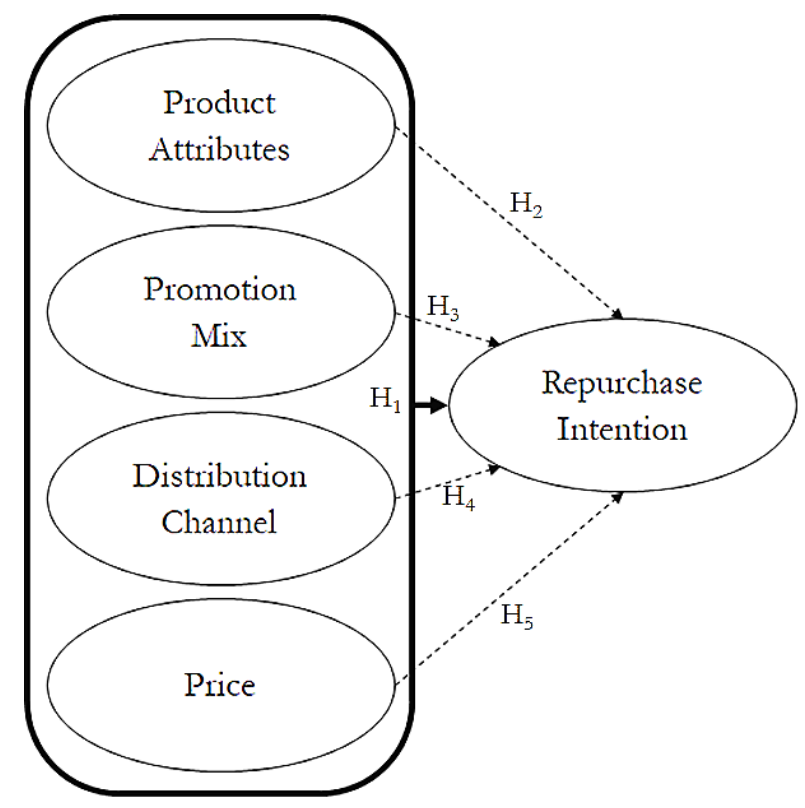

Figure 2. Conceptual Framework

\section{Research Methods}

This research is a type of quantitative research, namely a research approach that emphasizes analysis on numerical data (numbers) that are processed by statistical methods, as well as in the form of hypothesis testing using survey methods (Neuman, 2011). The quantitative research is causal, which means that research conducted to detect the causal relationship of one or more variables on one or more other variables, and to explain it by providing empirical evidence to support or refute a new phenomenon, which is based on previous theories or research (Sekaran, 2016).

Respondents in this study were 99 college student in Yogyakarta. The sampling technique uses non-probability - purposive sampling. The samples used as respondents were college students in Yogyakarta who had an iPhone and were included in the category of young adults aged 18-24 years (Auter, 2007). The data collection method used in this study was a questionnaire. The measurement of the data carried out in this study was a Likert scale with the following 
measurements: the answer "strongly agree" was given a score of 5, the answer "agree" was given a score of 4, the answer "neutral" was given a score of 3 , the answer "disagree" was given a score of 2 , the answer "strongly disagree" was given a score of 1.

Validity testing is carried out to determine whether the measuring instrument used correctly measures what you want to measure or not. The high and low validity of a measuring instrument is calculated by product moment correlation. The decision criteria for whether the questionnaire is valid or not is stated if the $r$ value obtained from the calculation ( $r x y)>$ from the $r$ value of the product moment table with a significant rate of $5 \%$, then the questions on the questionnaire are valid. While the decision criteria for the reliability of the questionnaire is stated if rvalue $>$ rtable $(\mathrm{r} 0>\mathrm{r} 1)$ can be declared reliable (Hair et al., 2010). The analytical technique used in this research is multiple linear regression analysis, $\mathrm{F}$ test and $\mathrm{t}$ test. All tests using IBM SPSS software version 23.

\section{Results and Discussion}

The questionnaire can be said to be valid for each instrument if all the questions are positively correlated to the variables and statistically significant, the results obtained from testing in IBM SPSS 23 and the reliability testing used in this study using Cronbach Alpha, where a questionnaire is said to be reliable if the Cronbach Alpha is greater than 0.60. All the questions in this study are valid and reliable as can be seen in Table 1 below:

Table 1. Validity Test, Reliability Test and Multiple Regression

\begin{tabular}{|c|c|c|c|c|c|c|}
\hline \multirow{2}{*}{ Variable } & \multirow{2}{*}{$\begin{array}{l}\text { Question } \\
\text { Items }\end{array}$} & \multirow{2}{*}{$\begin{array}{c}\mathrm{R} \\
\text { Value }\end{array}$} & \multirow{2}{*}{ Validity } & \multirow{2}{*}{$\begin{array}{l}\text { Cronbach's } \\
\text { Alpha }\end{array}$} & \multicolumn{2}{|c|}{$\begin{array}{c}\text { Unstandardized } \\
\text { Coefficients }\end{array}$} \\
\hline & & & & & $\mathrm{B}$ & $\begin{array}{l}\text { Std. } \\
\text { Error }\end{array}$ \\
\hline Constant & & & & & 3.287 & 2.425 \\
\hline \multirow{7}{*}{$\begin{array}{l}\text { Product Attribute } \\
\qquad\left(\mathrm{X}_{1}\right)\end{array}$} & 1 & 0,744 & Valid & \multirow{7}{*}{0.737} & \multirow{7}{*}{0.226} & \multirow{7}{*}{0.123} \\
\hline & 2 & 0,569 & Valid & & & \\
\hline & 3 & 0,729 & Valid & & & \\
\hline & 4 & 0,634 & Valid & & & \\
\hline & 5 & 0,557 & Valid & & & \\
\hline & 6 & 0,631 & Valid & & & \\
\hline & 7 & 0,783 & Valid & & & \\
\hline \multirow{7}{*}{$\begin{array}{c}\text { Promotion Mix } \\
\left(\mathrm{X}_{2}\right)\end{array}$} & 1 & 0,619 & Valid & \multirow{7}{*}{0.767} & \multirow{7}{*}{0.140} & \multirow{7}{*}{0.072} \\
\hline & 2 & 0,711 & Valid & & & \\
\hline & 3 & 0,679 & Valid & & & \\
\hline & 4 & 0,745 & Valid & & & \\
\hline & 5 & 0,728 & Valid & & & \\
\hline & 6 & 0,771 & Valid & & & \\
\hline & 7 & 0,576 & Valid & & & \\
\hline \multirow{3}{*}{$\begin{array}{c}\text { Distribution Channel } \\
\qquad\left(\mathrm{X}_{3}\right)\end{array}$} & 1 & 0,756 & Valid & \multirow{3}{*}{0.782} & \multirow{3}{*}{0.130} & \multirow{3}{*}{0.159} \\
\hline & 2 & 0,736 & Valid & & & \\
\hline & 3 & 0,713 & Valid & & & \\
\hline \multirow{4}{*}{$\begin{array}{l}\text { Price } \\
\left(\mathrm{X}_{4}\right)\end{array}$} & 1 & 0,743 & Valid & \multirow{4}{*}{0.717} & \multirow{4}{*}{0.285} & \multirow{4}{*}{0.133} \\
\hline & 2 & 0,746 & Valid & & & \\
\hline & 3 & 0,649 & Valid & & & \\
\hline & 4 & 0,802 & Valid & & & \\
\hline \multirow{5}{*}{$\begin{array}{l}\text { Repurchase Intention } \\
\qquad(\mathrm{Y})\end{array}$} & 1 & 0,684 & Valid & \multirow{5}{*}{0.798} & & \\
\hline & 2 & 0,794 & Valid & & & \\
\hline & 3 & 0,702 & Valid & & & \\
\hline & 4 & 0,736 & Valid & & & \\
\hline & 5 & 0,790 & Valid & & & \\
\hline
\end{tabular}

Based on Table 2, the F-value is 11.434 so that F-value $>$ than F-table $(11.434>2.46) \alpha=$ 0.05 . So that the product attribute variables $\left(\mathrm{X}_{1}\right)$, promotion mix $\left(\mathrm{X}_{2}\right)$, distribution channel $\left(\mathrm{X}_{3}\right)$, 
and price $\left(\mathrm{X}_{4}\right)$ simultaneously have an effect on consumers' repurchase intentions $(\mathrm{Y})$ because the F-value $(11,434)>$ F-table $(2.46)$. This means that product attributes, promotion mix, distribution channels, price have been able to make a significant contribution in increasing consumers' repurchase intentions, so the first hypothesis in this study is accepted.

Table 2. ANOVA(b)

\begin{tabular}{lcccccc}
\hline Model & Sum of Squares & df & Mean Square & F & Sig. \\
& & & & & \\
\hline Regression & 207.662 & 4 & 51.923 & 11.434 & 0.000 \\
Residual & 427.32 & 95 & 4.448 & & \\
Total & 634.172 & 97 & & & \\
\hline
\end{tabular}

a. Predictors: (Constant), Total Price, Total Distribution Channel, Total Promotion Mix, Total Product Attribute

b. Dependent Variable: Total Repurchase Intention

Based on Table 3, it can be seen that:

1. The t-value of the product attribute variable $\left(\mathrm{X}_{1}\right)$ is 2.046 , which is greater than the $\mathrm{t}$-table of $1.66(2.046>1.66)$ and the value of Sig. $<$ alpha $(0.046<0.05)$. Thus it can be concluded that $\mathrm{H}_{2}$ is accepted, which means that the product attribute variable $\left(\mathrm{X}_{1}\right)$ has an effect on repurchase intention $(\mathrm{Y})$. So, the more attractive the product attributes on iPhone, the higher the consumer's repurchase intention for the iPhone.

2. The t-value of the promotion mix variable $\left(\mathrm{X}_{2}\right)$ is 2.043 which is greater than the t-table of $1.66(2.043>1.66)$ and the value of Sig. $<$ alpha $(0.047<0.05)$. Thus it can be concluded that $\mathrm{H}_{3}$ is accepted, which means that the promotion mix variable $\left(\mathrm{X}_{2}\right)$ has an effect on repurchase intention $(\mathrm{Y})$. So, the more attractive the promotion mix, the more consumers' intention to repurchase the iPhone will increase.

3. The t-value of the distribution channel variable $\left(X_{3}\right)$ is 0.788 smaller than the t-table of 1.66 $(0.788<1.66)$ and the value of Sig. $>$ alpha $(0.437>0.05)$. Thus it can be concluded that $\mathrm{H}_{4}$ is rejected, which means that the distribution channel variable $\left(\mathrm{X}_{3}\right)$ has no effect on repurchase intention $(\mathrm{Y})$. So, the easier it is for consumers to get the product, it will not affect the consumer's repurchase intention on the product.

4. The $\mathrm{t}$-value of the price variable $\left(\mathrm{X}_{4}\right)$ is 2.185 , which is greater than the $\mathrm{t}$-table of $1.66(2.185$ $>1.66)$ and the value of Sig. $<$ alpha $(0.032<0.05)$. Thus it can be concluded that $\mathrm{H}_{5}$ is accepted, meaning that the price variable $\left(\mathrm{X}_{4}\right)$ has an effect on repurchase intention $(\mathrm{Y})$. So, the more competitive the price of the product in the market, the higher the consumer's intention to repurchase iPhone products.

Table 3. Coefficients(a)

\begin{tabular}{llccccc}
\hline \multirow{2}{*}{ Model } & \multicolumn{2}{c}{$\begin{array}{c}\text { Unstandardized } \\
\text { Coefficients }\end{array}$} & $\begin{array}{c}\text { Standardized } \\
\text { Coefficients }\end{array}$ & t & Sig. \\
\cline { 3 - 5 } & B & Std. Error & Beta & & \\
\hline 1 & (Constant) & 3.287 & 2.538 & & 1.362 & 0.189 \\
& Total Product Attribute & 0.216 & 0.102 & 0.233 & 2.046 & 0.046 \\
Total Promotion Mix & 0.148 & 0.078 & 0.198 & 2.043 & 0.047 \\
Total Distribution Channel & 0.138 & 0.15 & 0.074 & 0.788 & 0.437 \\
Total Price & 0.274 & 0.154 & 0.235 & 2.185 & 0.032 \\
\hline
\end{tabular}

a. Dependent Variable: Total Repurchase Intention

\section{Implication and Conclusion}

Based on the results of research and the results of data analysis that has been done regarding the effect of product attributes, promotion mix, distribution channels, and prices on consumers' 
repurchase intentions on the iPhone, it can be concluded that based on the F test, product attribute, promotion mix, distribution channels, and price have a simultaneous effect on consumers' repurchase intentions towards iPhone. Based on the t-test, the price variable is the most dominant variable influencing consumers' repurchase intention towards iPhone, followed by product attribute and promotion mix. Therefore, this study supports previous researches (Gherasim \& Gherasim, 2019; Song et al., 2020; Ji \& Ha, 2021). On the contrary, the distribution channel variable has no effect on consumers' repurchase intentions towards iPhone.

From these conclusions, the researchers suggest that the company must improve the price strategy that is carried out while still prioritizing the needs and abilities of consumers to be able to reach prices. The next suggestion is the company may improves everything related to product attributes to create an attractive impression and consumers will be enthusiastic to buy again. The following suggestion is company should increase the promotion mix on the iPhone, for example by increasing the creativity of iPhone advertising or by sponsoring famous artists or influencers as iPhone advertising stars so that it will still create a strong positioning in the minds of consumers.

Although this research is mostly supported empirically, it still has some limitations. First limitation, this research was conducted only at one time due to limited research resources. The second limitation is related to objects research. The brands studied in this study are limited to global brands in the smartphone industry (iPhone). Some of the limitations in this study can be used as suggestions for future research. First, future research can apply longitudinal studies. Second, further research is expected to conduct a broader and comprehensive test by developing a qualitative research approach or adding several new variables related to repurchase intention behavior such as product quality or brand image. Third, further research can change brands that are different from this study, or use research objects other than smartphones, such as laptops or non-electronic goods such as vehicles or apparel.

\section{References}

Above Avalon (2020). A Billion iPhone Users. Retrieved from https://www.aboveavalon.com/notes/2020/10/26/a-billion-iphone-users at 2 May 2021.

Armstrong, G. and Kotler, P. (2015), Marketing: an Introduction. $12^{\text {th }}$ edition, Global Edition. USA: Pearson Education, Inc.

Attia, M. A. S., Chepyator-Thomson, J., Sonkeng, K., and el Azim, Hazem Kamal El-Din Abd. (2018). Use of sport promotion mix to increase consumption of services: A case study of el-hawwar sport club in egypt. The ICHPER-SD Journal of Research in Health, Physical Education, Recreation, Sport \& Dance, 10(1), 28-38.

Backer, E. (2010). Using Smartphone and Facebook in A Major Assessment: The Student Experience. e-Journal of Business Education \& Scholarship of Teaching. 4(1), 19-31.

Butcher, L. M., Ryan, M. M., Therese A O’Sullivan, Lo, J., and Devine, A. (2019). Food-insecure Household's self-reported perceptions of food labels, product attributes and consumption behaviours. Nutrients, 11(4), 828.

Chang, Y., Min-Fang, W., and Luh, Y. (2021). Choice of modern food distribution channels and its welfare effects: Empirical evidence from Taiwan. Agriculture, 11(6), 499.

Etzel, M., Walker, B.J., Stanton, W.J., and Pandit, A. (2017). Marketing. United Kingdom: McGraw Hill Education/Irwin.

Fikri, M., and Lisdayanti, A. (2020). Analysing promotion mix and perceived usefulness of e-wallets: A case of linkaja applications in Indonesia. International Journal of Finance \& Banking Studies, 9(1), 76-84.

Gazdecki, M. (2018). Factors of business relationships change in agribusiness input distribution channel: The case of polish market. The IMP Journal, 12(3), 567-582. 
Gherasim, A., Gherasim, D., and Vasiloaia, M. (2012). Communication in marketing promotion. Economy Transdisciplinarity Cognition, 15(1), 293-299A

Gherasim, D., and Gherasim, A. (2019). Strategies regarding prices within the international marketing. Economy Transdisciplinarity Cognition, 22(1), 62-67.

Handoko, T.H. (2017), Manajemen. 2nd edition. Yogyakarta: BPFE Yogyakarta.

Hair, J.F., Black, W.C., Babin, B.J., Anderson, R.E., and Tatham, R.L. (2010), Multivariate Data Analysis. 7th ed. New York: Pearson.

Hersh, A., and Aladwan, k. (2015). Tourists perceive marketing deception through the promotional mix. Business Management Dynamics, 4(12), 21-35.

Jeon, Y., Kim, D., Han, S., Huang, Y., and Kim, J. (2021). How does service environment enhance consumer loyalty in the sport fitness industry? the role of service scape, consumption motivation, emotional and flow experiences. Sustainability, 13(11), 1-17.

Ji, K., and Ha, H. (2021). An empirical test of mobile service provider promotions on repurchase intentions. Sustainability, 13(5), 2894.

Kadar, K. (2018). Promotion of tourist attractions and identification of the promotional marketing mix applied by travel agencies in the centre region of Romania. Bulletin of the Transilvania University of Brasov.Economic Sciences.Series V, 11(1), 55-62.

Kim, N. L., Kim, G., and Rothenberg, L. (2020). Is honesty the best policy? examining the role of price and production transparency in fashion marketing. Sustainability, 12(17), 6800.

Kotler, P.T., and Armstrong, G. (2017). Principles of Marketing $17^{\text {th }}$ Edition. United Kingdom: Pearson Education, Inc.

Kotler, P.T. and Keller, K.L. (2016), Marketing Management. 15 th edition, Global Edition. UK: Pearson Education, Inc.

Lee, D., Byon, K. K., Schoenstedt, L., Johns, G., Bussell, L. A., and Choi, H. (2012). Validation of the consumer values versus perceived product attributes model measuring the purchase of athletic team merchandise. The ICHPER-SD Journal of Research in Health, Physical Education, Recreation, Sport \& Dance, 7(2), 52-58

Li, X., Baolong, M., and Rubing, B. (2020). Do you respond sincerely? how sellers' responses to online reviews affect customer relationship and repurchase intention. Frontiers of Business Research in China, 14(1), 1-13.

Lo, C.H., Liao, G.Y., Tang, Z.X., Chen, X.W., Xu, H.F., and Hu, J. (2018). A Study of iPhone’s Attractiveness Factors by the Miryoku Engineering Approach. KnE Social Sciences, 3(10), 1680-1690.

Lovelock, C.H., and Wright, L.K. (2011). Principles of Service Marketing and Management. United States: Prentice Hall.

Mankiw, N.G. (2012). Principles of economics 6th edition. Philippine Edition: Cengage Learning.

Mendoza, E. C. (2021). A study of online customers repurchase intention using the 4Rs of marketing framework. International Review of Management and Marketing, 11(2), 1-10.

Muhammad, A., Jiang, Y., Waheed, A., Khan, M. S., and Muhammad, F. (2019). Customers' expectation, satisfaction, and repurchase intention of used products online: Empirical evidence from china. Sage Open, 9(2), 1-14.

Neuman, W.L. (2011), Social Research Methods; Qualitative and Quantitative Approaches, $7^{\text {th }}$ edition. United Kingdom: Pearson New International Edition.

Peter, J.P., and Olson, J.C. (2010). Consumer Behavior \& Marketing Strategy 9th edition. United Kingdom: McGraw Hill Education/Irwin. 
Pham, Q. H., and Huynh, V. K. (2020). Transaction cost, price risk perspective and marketing channel decision of small-scale chili farmers in tra vinh province, vietnam. Asian Journal of Agriculture and Rural Development, 10(1), 68-80.

Pindyck, R.S., and Rubinfeld, D.L. (2018) Microeconomics. Ninth edition, global edition. United Kingdom: Pearson Education.

Puspaningrum, A. (2018). Hypermarket customer loyalty: Product attributes and image mediated by value and customer satisfaction. Journal of Business and Retail Management Research, 13(2), 84-97.

Rasmikayati, E., Saefudin, B. R., Wardhana, M. Y., and Baihaqi, A. (2021). Comparative analysis of coffee preference in jatinangor. IOP Conference Series. Earth and Environmental Science, 644(1), $1-15$.

Sekaran, U., and Bougie, R.J. (2016). Research Methods for Business: A Skill Building Approach. $7^{\text {th }}$ edition. Germany: John Wiley and Son, Inc.

Simanjuntak, M., Sumarwan, U., and Situmorang, A. D. (2020). The effect of marketing mix and brand image on customer loyalty of remixed mortar. Independent Journal of Management \& Production, 11(2), 450-472.

Solomon, M.R., Marshall, G.W., and Stuart, E.W. (2018), Marketing: Real People, Real Choices. $9^{\text {th }}$ Edition. United Kingdom: Pearson Education, Inc.

Song, H., Shin, G. W., Yoon, Y., and Bahn, S. (2020). The effects of ear dimensions and product attributes on the wearing comfort of wireless earphones. Applied Sciences, 10(24), 8890.

Thabit, T. H., and Raewf, M. B. (2018). The evaluation of marketing mix elements: A case study. International Journal of Social Sciences \& Educational Studies, 4(4), 100-109.

Tocci, Meghan (2020). History and Evolution of Smartphones. Retrieved from https://simpletexting.com/where-have-we-come-since-the-first-smartphone/ at 2 May 2021.

Tošović-Stevanović, A., Ristanović, V., Ćalović, D., Lalić, G., Žuža, M., and Cvijanović, G. (2020). Small farm business analysis using the AHP model for efficient assessment of distribution channels. Sustainability, 12(24), 10479.

Urdea, A.M., Constantin, C.P., and Purcaru, I.M (2021). Implementing experiential marketing in the digital age for a more sustainable customer relationship. Sustainability, 13(4), 1865

Vlad, F., and Pavel, C. (2017). The operation of distribution channels for the marketing of petroleum products. Quaestus, (11), 25-30.

Williams, B.K., and Sawyer, S.C. (2011). Using Information Technology: A Practical Introduction to Computers \& Communications. (9 ${ }^{\text {th }}$ edition). New York: McGraw-Hill.

Yarosh, O. B., and Mitina, E. A. (2020). Market of organic products in regions: Distribution channels and development strategy. Ekonomika Regiona, (1), 141-156.

Yun, B.S., Lee, S.G. and Aoshima, Y. (2019). An analysis of the trilemma phenomenon for Apple iPhone and Samsung Galaxy. Serv Bus, 13, 779-812. 